\title{
POTENTIAL AGROFORESTRY SYSTEMS FOR SEMIARID REGIONS
}

\author{
Erick Martins Nieri ${ }^{1 *}$, Rodolfo Soares de Almeida ${ }^{2}$, Renato Luiz Grisi Macedo ${ }^{2}$, Wagner Massote Magalhães ${ }^{2}$, \\ Nelson Venturin ${ }^{2}$, Emilio Manabu Higashikawa ${ }^{2}$ \\ 1*Universidade Federal do Sul e Sudeste do Pará, Instituto de Estudos do Xingu, Curso de Engenharia Florestal, São Félix do Xingu, Pará, \\ Brasil - e-mail: ericknieri@unifesspa.edu.br \\ ${ }^{2}$ Universidade Federal de Lavras, Programa de Pós-graduação em Engenharia Florestal, Lavras, Minas Gerais - e-mail: \\ rodolfoflorestal@gmail.com; rlgrisi@dcf.ufla.br; magalhaeswm@gmail.com; venturin@dcf.ufla.br; emilio.higashikawa@gmail.com
}

Received for publication: 03/09/2019 - Accepted for publication: 20/08/2020

\begin{abstract}
Resumo
Potencial de utilização de sistemas agroflorestais para regiões semiáridas. O objetivo deste trabalho foi avaliar o potencial dos sistemas agroflorestais no semiárido, e avaliar a produtividade do eucalipto em três espaçamentos de plantio, em cultivo solteiro em sistemas agroflorestais. A comparação dos sistemas foi em delineado de blocos casualizados com quatro sistemas (monocultivo; sistemas com amendoim; mamona; mandioca) e três espaçamentos de eucalipto ( $10 \mathrm{~m}$ x $2 \mathrm{~m}, 10 \mathrm{~m} \times 3 \mathrm{~m}$ e $10 \mathrm{~m} \times 4 \mathrm{~m}$ ). Os monocultivos e demais características foram comparados pelo delineamento de blocos casualizados. Aos três meses e meio avaliou-se a produtividade do amendoim, aos cinco e oito meses mensurou-se a produtividade da mamona e aos 21 meses a da mandioca. A produtividade do eucalipto foi mensurada aos 13 e 21 meses de idade. Os resultados mostraram que a produção de madeira foi maior no espaçamento $10 \mathrm{~m} \times 2 \mathrm{~m}$ e no sistema com mamona e cultivo solteiro. A produtividade da mamona foi superior em sistema, no espaçamento $10 \mathrm{~m} \times 3 \mathrm{~m}$, enquanto que a produtividade da mandioca foi superior em monocultivo. O índice de equivalência de área dos sistemas fora superior aos monocultivos. Portanto, sistemas agroflorestais de eucalipto consorciados com mamona e mandioca são adequados para a região semiárida. O espaçamento $10 \mathrm{~m} \mathrm{x} 2 \mathrm{~m}$ proporcionou maior volume em madeira $\left(\mathrm{m}^{3} \mathrm{ha}^{-1}\right)$. A produtividade de mamona foi maior no espaçamento $10 \mathrm{~m} \times 3 \mathrm{~m}$. Para a mandioca, o maior rendimento foi obtido na monocultura e no sistema com espaçamento de $10 \mathrm{~m}$ x $3 \mathrm{~m}$ ou $10 \mathrm{~m}$ x $4 \mathrm{~m}$.

Palavras-chave: Sistemas Silviagrícolas, Consórcio, Espaçamento, Índice de equivalência de área.
\end{abstract}

\begin{abstract}
The objective of this work was to evaluate the potential of agroforestry systems in the semiarid, and to evaluate the productivity of eucalyptus in three planting spacing, in single cultivation in agroforestry systems. The comparison of the systems was in a randomized block design with four systems (monoculture; peanut systems; castor bean; cassava) and three eucalyptus spacing (10 m x $2 \mathrm{~m}, 10 \mathrm{~m}$ x $3 \mathrm{~m}$ and $10 \mathrm{~m}$ x $4 \mathrm{~m})$. Monocultures and other characteristics were compared by randomized block design. Peanut productivity was evaluated at three and a half months, castor productivity at five and eight months and cassava productivity at 21 months. Eucalyptus productivity was measured at 13 and 21 months of age. The results showed that the wood production was greater in the $10 \mathrm{~m} \times 2 \mathrm{~m}$ spacing and in the system with castor and single cultivation. The castor yield was higher in the system, in the $10 \mathrm{~m} \times 3 \mathrm{~m}$ spacing, while the cassava productivity was higher in monoculture. The area equivalence index of the systems was higher than that of monocultures. Therefore, eucalyptus agroforestry systems intercropped with castor and cassava are suitable for the semiarid region. The $10 \mathrm{~m} \times 2 \mathrm{~m}$ spacing provided a larger volume of wood $\left(\mathrm{m}^{3}\right.$ ha-1). Castor yield was higher in the $10 \mathrm{~m} \times 3 \mathrm{~m}$ spacing. For cassava, the highest yield was obtained in monoculture and in the system with $10 \mathrm{~m} \times 3 \mathrm{~m}$ or $10 \mathrm{~m} \mathrm{x} 4 \mathrm{~m}$ spacing. Key words: Agrosilviculture, Consortium, Spacing, Area equivalence index.
\end{abstract}

\section{INTRODUCTION}

Agroforestry systems enable the production of wood and food in the same area, using the natural resources available in the ecosystem in a rational and sustainable way to meet the growing needs of the world population (MACEDO et al., 2018). This system has become an alternative for sustainable development by providing diversified production and the possibility of a steady income with the marketing of agricultural products, while the forest grows in the same production area (MACEDO et al., 2018; NIERI et al., 2018).

Semiarid regions are defined by their climatic features, such as strong insolation, high temperatures, and scarce and irregular rain regimes (SILVA et al, 2010). These characteristics undermine agricultural productive capacity, narrowing the possibilities of crops to develop without the increased use of technologies to meet climatic demands. As an example, the Brazilian semiarid regions present a maximum annual precipitation of $800 \mathrm{~mm}$, an average of $2,800 \mathrm{~h}_{\text {year }}{ }^{-1}$, with average annual temperature of $23^{\circ} \mathrm{C}$ to $27^{\circ} \mathrm{C}$, evaporation of $2,000 \mathrm{~mm}$ year ${ }^{-1}$, and relative humidity of approximately $50 \%$. This region is home to approximately 22 million people and comprises an area of $982,563.3 \mathrm{~km}^{2}$ with 1,133 municipalities.

FLORESTA, Curitiba, PR, v. 51, n. 2, p. 363-370, abril/jun 2021

Nieri, E. M. et.al.

ISSN eletrônico 1982-4688 
The most common crops cultivated under such harsh climatic conditions are arable crops (171 ha), castor beans (210 ha), and cassava (17,355 ha), in the semiarid region of Minas Gerais State according to IBGE (2016). These crops are well adapted, and each is economically important.

Castor beans are of tropical origin, are fairly drought-resistant, and thrive in bright sunlight. They adapt to many types of soil, except those heavy in clay or salt. The use of oil for biodiesel production has caused an increase in the demand for this crop (MATEUS et al., 2015). Cassava has wide adaptability and is a culture of social importance in Brazil. Its rhizome provides carbohydrate sources for human nutrition, and rest of the plant can be used as animal feed (SOARES et al., 2017). Peanuts are well adapted to hot climates and sandy soils, and are used in the human diet in the same role as cassava (DUARTE et al., 2013).

Eucalyptus is another well-suited semiarid plant because of its wide ecological plasticity. Some species exhibit drought resistance and a strong growth rate in semiarid environments. Agroforestry systems using Eucalyptus, peanut, castor bean, and cassava show good potentials for use in semiarid regions because they have adapted to the edaphoclimatic conditions of these areas.

Another important aspect of agroforestry systems is the plant spacing of the tree lines, in relation to the fact that crops are commonly planted between tree rows. The distances and the growth rate of the tree component in the system define the amount of sunlight at the disposal of the crops, and the length of time that the agricultural component of the system can be productive (SOBBULAKSHMI et al., 2019). The choice of species and the spacing between the tree lines are among the most important decisions when planning agroforestry systems.

In this context, this study aimed to: a) evaluate the production of agroforestry systems with Eucalyptus intercropped with peanuts, castor bean, and cassava planted in three spacings of tree rows, and b) compare and quantify the monoculture production of the agricultural and intercropped species with Eucalyptus.

\section{MATERIAL AND METHODS}

The experimental area was located in the city of Taiobeiras, in the north of the state of Minas Gerais, in a region owned by a charcoal producing company located at coordinates $15^{\circ} 48^{\prime} 28^{\prime \prime} \mathrm{S}$ and $42^{\circ} 13^{\prime} 59^{\prime \prime} \mathrm{W}$ and altitude of $821 \mathrm{~m}$. The area has a semiarid climate, average annual temperature in the range of $22^{\circ} \mathrm{C}$ to $24^{\circ} \mathrm{C}$, and average annual rainfall of $800 \mathrm{~mm}$, concentrated between the months of November and February (ALVARES et al., 2013).

The tree component of the agroforestry system was Eucalyptus urophylla S. T. Blake, a commercial clone (I-60), which was intercropped with the agricultural components of peanut (Arachis hipogea L. - variety TatuST), castor bean (Ricinus communis L., variety Guarany), and cassava (Manihot esculenta Crantz - IAC-12).

The area was prepared by removing the previous vegetation, two soil harrowing of the total area, and subsoiling only in the tree lines. Soil correction and fertilization were specific to each culture and system. For Eucalyptus, $1.5 \mathrm{t} \mathrm{ha}^{-1}$ of limestone was applied to the strip, and $150 \mathrm{~kg} \mathrm{ha}^{-1}$ of triple superphosphate with $0.5 \%$ of boron was added to the subsoil furrow for soil correction. Fertilization consisted of $108 \mathrm{~g} \mathrm{plant}^{-1} \mathrm{~N}$ : P: K (06:30:06 $+\mathrm{Cu}$ and $\mathrm{Zn})$ applied in lateral holes and $100 \mathrm{~g} \mathrm{plant}^{-1}(\mathrm{~N}: \mathrm{P}: \mathrm{K}$ 12:00:18 + 0.5\% B) applied under the canopy projection 90 days after planting.

For peanut fertilization, 7.0 tons $\mathrm{ha}^{-1}$ of limestone, 1.5 ton ha ${ }^{-1}$ of agricultural gypsum, $100 \mathrm{~kg} \mathrm{ha}^{-1}$ of $\mathrm{KCl}$, and $200 \mathrm{~kg} \mathrm{ha}^{-1}$ of triple superphosphate was used. The castor beans were allocated $4.0 \mathrm{t} \mathrm{ha}^{-1}$ of limestone, $750 \mathrm{~kg}$ $\mathrm{ha}^{-1}$ of agricultural gypsum, and $200 \mathrm{~kg} \mathrm{ha}^{-1}$ of $\mathrm{N}: \mathrm{P}: \mathrm{K}(08: 28: 16+0,9 \% \mathrm{Zn})$. For cassava, $2.0 \mathrm{t} \mathrm{ha}^{-1}$ of limestone, $750 \mathrm{~kg} \mathrm{ha}^{-1}$ of agricultural gypsum, and $170 \mathrm{~kg} \mathrm{ha}^{-1}$ of $\mathrm{N}: \mathrm{P}: \mathrm{K}(08: 28: 16+0.9 \% \mathrm{Zn})$ was added.

The monocultures were planted with a cultural spacing: peanut $0.6 \mathrm{~m} \times 0.1 \mathrm{~m}$, castor bean $1.6 \mathrm{~m} \times 1.0 \mathrm{~m}$, and cassava $0.9 \mathrm{~m} \times 0.9 \mathrm{~m}$. To create the agroforestry systems the spacing between trees was $10 \mathrm{~m} \times 2 \mathrm{~m}, 10 \mathrm{~m} \times$ $3 \mathrm{~m}$, and $10 \mathrm{~m} \times 4 \mathrm{~m}$, and the crops (peanut, castor bean, and cassava) were cultivated between the tree lines with the same spacing as the monocultures, keeping one and a half meters distant from the trees. The conduction was carried out according to the specifications of each crop, not differentiating the cultural treatments between the monocultures and the systems.

To quantify crop production, random plots were placed in both crop fields, monoculture, and agroforestry systems. The sampling unit consisted of two lines of three linear meters for the peanut, three lines of nine linear meters for the castor bean, and three lines of ten linear meters for the cassava. Peanut production was determined at three and a half months by manual harvesting, weighing, and extrapolating per hectare. Castor beans were harvested at five and eight months, the berries were weighed, and production estimated by extrapolation. At 21 months, the cassava was harvested, the roots were weighed, and the production results were estimated per hectare.

To estimate the volume, eight trees in each spacing were strictly cubed by the Smalian method at 13 and 21 months, and volumetric equations were obtained for each Eucalyptus plant spacing at each age. To obtain the volume per hectare, some of the individual parcel volumes were extrapolated to a hectare. In this study, only the productions were presented, with the published equations being a part of the function of their complexity and space limit.

FLORESTA, Curitiba, PR, v. 51, n. 2, p. 363-370, abril/jun 2021. 
The experiment contained three designs to evaluate the different responses. To understand wood production between the systems, we used a statistical, randomized complete block design in a $4 \times 3$ factorial with four systems (Eucalyptus as a monoculture, and systems with peanut, castor bean, and cassava), and three tree spacings $(10 \mathrm{~m} \times 2 \mathrm{~m}, 10 \mathrm{~m} \times 3 \mathrm{~m}$, and $10 \mathrm{~m} \times 4 \mathrm{~m})$, with three replicates. A completely randomized design with six replicates was utilized to compare the agricultural crop yield, using four treatments (monoculture, and systems with $10 \mathrm{~m} \times 2 \mathrm{~m}, 10 \mathrm{~m} \times 3 \mathrm{~m}$, and $10 \mathrm{~m} \times 4 \mathrm{~m}$ ) per culture. For the area equivalence index (AEI) a completely randomized block design with three replicates was used. The AEI was estimated using the equation of Mead and Willey (1980) (Equation 1).

$$
\mathrm{AEI}=(\mathrm{PFC} / \mathrm{PFM})+(\mathrm{PAC} / \mathrm{PAM}) \quad(\text { Equation } 1)
$$

Where: $\mathrm{AEI}=$ Area Equivalence Index;

$\mathrm{PFC}=$ production of the consortium forest component;

$\mathrm{PFM}=$ production of the forest component in monoculture;

$\mathrm{PAC}=$ production of the consortium agricultural component $;$ and

$\mathrm{PAM}=$ production of the agricultural component in monoculture.

The data obtained for the volume and the agricultural production per hectare were submitted to analysis of variance, and if significant at $5 \%$ by the Fisher test, the Tukey averages test at $5 \%$ of error probability was applied. For the analysis of AEI data, the Scott-Knott averages grouping test was used at a 5\% probability of error.

\section{RESULTS}

The analysis of variance for volume per hectare showed significant differences $(\mathrm{p}<0.05)$ for spacing, system, and their interaction at the $95 \%$ confidence level in the 13 and 21 month evaluations. A significant difference $(\mathrm{p}<0.05)$ was observed in the production of castor bean and cassava.

We were not able to perform the analysis of variance of peanut production due to missing information in the stand, high production heterogeneity in terms of green grains, and the presence of pathogens. There was a significant difference in the area equivalence index $(\mathrm{p}<0.01)$ among the systems studied.

\section{Eucalyptus production}

The Tukey test $(\mathrm{p}<0.05)$ presents the results of the system interactions for each spacing and age assessed (Table 1). A higher wood volume per hectare was obtained in agroforestry systems intercropped with castor bean, and single cultivated Eucalyptus at both ages and tree spacings. An exception was observed for the spacing of 10 $\mathrm{m} \times 3 \mathrm{~m}$ at 21 months, in which the highest wood volume per hectare was shown only for the agroforestry systems with castor bean.

Table 1. Eucalyptus urophylla initial productivity in volume per hectare $\left(\mathrm{m}^{3} \mathrm{ha}^{-1}\right)$ in agroforestry systems for different spacing in semiarid regions at 13 and 21 months.

Tabela 1. Produtividade inicial de Eucalyptus urophylla em volume por hectare (m3 ha-1) em sistemas agroflorestais para diferentes espaçamentos no semiárido aos 13 e 21 meses.

\begin{tabular}{|c|c|c|c|c|c|c|c|c|c|c|c|}
\hline \multirow{3}{*}{$\frac{\text { System }}{\text { Eucalyptus with peanut }}$} & \multicolumn{6}{|c|}{13 months } & \multicolumn{5}{|c|}{21 months } \\
\hline & \multicolumn{2}{|c|}{$10 \times 2$} & \multicolumn{2}{|c|}{$10 \times 3$} & \multicolumn{2}{|c|}{$10 \times 4$} & \multicolumn{2}{|c|}{$10 \times 2$} & \multicolumn{2}{|c|}{$10 \times 3$} & \multirow{2}{*}{$\frac{10 \times 4}{11.31 \mathrm{Cb}}$} \\
\hline & 2.51 & $\mathrm{Ab}$ & 1.90 & $\mathrm{ABb}$ & 1.52 & $\mathrm{Bb}$ & 22.53 & Aab & 16.23 & $\mathrm{Bb}$ & \\
\hline Eucalyptus with castor beans & 3.35 & $\mathrm{Aa}$ & 3.46 & Aa & 1.90 & $\mathrm{Bab}$ & 24.99 & $\mathrm{Aa}$ & 20.95 & $\mathrm{Ba}$ & $13.82 \mathrm{Cab}$ \\
\hline Eucalyptus with cassava & 2.02 & $\mathrm{Ab}$ & 1.64 & $\mathrm{ABb}$ & 1.24 & $\mathrm{Bb}$ & 20.72 & $\mathrm{Ab}$ & 15.48 & $\mathrm{Bb}$ & $11.00 \mathrm{Cb}$ \\
\hline Eucalyptus & 3.40 & Aa & 2.74 & $\mathrm{ABa}$ & 2.58 & $\mathrm{Ba}$ & 23.48 & $\mathrm{Aab}$ & 17.32 & $\mathrm{Bb}$ & $16.07 \mathrm{Ba}$ \\
\hline Coefficient of variation (\%) & & & & 13.82 & & & & & 7.07 & & \\
\hline Average $\left(\mathrm{m}^{3} \mathrm{ha}^{-1}\right)$ & & & & 2.35 & & & & & 17.83 & & \\
\hline
\end{tabular}

Averages followed by the same lowercase letter in the same column, and upper case in the same row, do not differ significantly, according to the Tukey test $(\mathrm{p}<0.05)$.

As médias seguidas da mesma letra minúscula na mesma coluna e maiúsculas na mesma linha não diferem significativamente, de acordo com o teste de Tukey $(\mathrm{p}<0,05)$.

Analyzing the consortiums, the spacings of $10 \mathrm{~m} \times 2 \mathrm{~m}$ and $10 \mathrm{~m} \times 3 \mathrm{~m}$ presented the same performance among all the systems after 13 months. Among all systems, the highest volume per hectare was the $10 \mathrm{~m} \times 2 \mathrm{~m}$ spacing after 21 months. 


\section{Productivity of the agricultural component}

The analysis of variance showed a significant difference in the production of castor bean and cassava, with a 5\% error probability. The Tukey test presented the average productivity values of castor bean and cassava at an error probability of $5 \%(\mathrm{p}<0.05)$ (Table 2$)$.

Table 2. Average yield of castor bean and cassava $\left(\mathrm{kg} \mathrm{ha}^{-1}\right)$ in monoculture and agroforestry systems with Eucalyptus in different spacing in the northern region of Minas Gerais.

Tabela 2. Produtividade média da mamona e mandioca $\left(\mathrm{kg} \mathrm{ha}^{-1}\right)$ nos sistemas monocultivo e agroflorestal com Eucalyptus em diferentes espaçamentos na região norte de Minas Gerais.

\begin{tabular}{lcccl}
\hline \multirow{2}{*}{ Spacing } & \multicolumn{4}{c}{ Productivity $\left(\mathrm{kg} \mathrm{ha}^{-1}\right)$} \\
\cline { 2 - 5 } & Castor beans & Cassava \\
\hline $10 \mathrm{~m} \times 2 \mathrm{~m}$ & 393.26 & $\mathrm{~b}$ & 8334.17 & $\mathrm{~b}$ \\
$10 \mathrm{~m} \times 3 \mathrm{~m}$ & 498.06 & $\mathrm{a}$ & 10338.82 & $\mathrm{ab}$ \\
$10 \mathrm{~m} \times 4 \mathrm{~m}$ & 296.81 & $\mathrm{c}$ & 10250.14 & $\mathrm{ab}$ \\
Monoculture & 267.08 & $\mathrm{c}$ & 12486.69 & $\mathrm{a}$ \\
\hline Coefficient of variation (\%) & 15.48 & 16.29 & \\
Average $\left(\mathrm{m}^{3} \mathrm{ha}^{-1}\right)$ & 363.80 & 10410.21 & \\
\hline
\end{tabular}

Averages followed by the same letter in the column do not differ significantly by Tukey's test at the 5\% error probability level.

Médias seguidas pela mesma letra na coluna não diferem significativamente pelo teste de Tukey no nível de probabilidade de erro de $5 \%$.

The production of castor bean was positively affected by the adoption of the system with Eucalyptus, as this resulted in higher yields when compared to conventional planting (monoculture). The $10 \mathrm{~m} \times 3 \mathrm{~m}$ system resulted in an $86 \%$ increase in castor bean production, which highlights the potential for these agroforestry systems in semiarid regions. The lowest production in a system was found in the $10 \mathrm{~m} \times 4 \mathrm{~m}$ spacing, which was similar to monoculture production.

Cassava production did not present differences between the systems, at $10 \mathrm{~m} \times 3 \mathrm{~m}$ and $10 \mathrm{~m} \times 4 \mathrm{~m}$ spacing, and traditional cultivation (monoculture).

\section{Area equivalence indexes (AEI)}

The area equivalence index (Table 3) was presented for the agroforestry systems studied, and it was noted that all the agroforestry systems presented results higher than 1.0. The highest values were found in the castor bean consortia, especially with the $10 \mathrm{~m} \times 3 \mathrm{~m}$ spacing (3.1). The systems with cassava showed no statistical differences among them.

Table 3. Area Equivalence Index (AEI) of Agroforestry Systems with Eucalyptus urophylla, cassava, and castor bean in the semiarid region.

Tabela 3. Índice de Equivalência de Área (IEA) de Sistemas Agroflorestais com Eucalyptus urophylla, mandioca e mamona no semiárido.

\begin{tabular}{|c|c|c|c|c|c|c|}
\hline \multirow{2}{*}{ Models of cultivation } & \multirow{2}{*}{ Castor beans } & \multirow{2}{*}{ Cassava } & \multicolumn{3}{|c|}{ Eucalyptus } & \multirow{2}{*}{ AEI } \\
\hline & & & $10 \times 2$ & $10 \times 3$ & $10 \times 4$ & \\
\hline Castor beans Monoculture & 1.0 & 0.0 & 0.0 & 0.0 & 0.0 & $1.0 \mathrm{e}$ \\
\hline Cassava Monoculture & 0.0 & 1.0 & 0.0 & 0.0 & 0.0 & $1.0 \mathrm{e}$ \\
\hline Eucalyptus $10 \mathrm{~m} \times 2 \mathrm{~m}$ & 0.0 & 0.0 & 1.0 & 0.0 & 0.0 & $1.0 \mathrm{e}$ \\
\hline Eucalyptus $10 \mathrm{~m} \times 3 \mathrm{~m}$ & 0.0 & 0.0 & 0.0 & 1.0 & 0.0 & $1.0 \mathrm{e}$ \\
\hline Eucalyptus $10 \mathrm{~m}$ x $4 \mathrm{~m}$ & 0.0 & 0.0 & 0.0 & 0.0 & 1.0 & $1.0 \mathrm{e}$ \\
\hline Castor beans with Eucalyptus $10 \mathrm{~m} \times 2 \mathrm{~m}$ & 1.5 & 0.0 & 1.1 & 0.0 & 0.0 & $2.6 \mathrm{~b}$ \\
\hline Castor beans with Eucalyptus $10 \mathrm{~m} \times 3 \mathrm{~m}$ & 1.9 & 0.0 & 0.0 & 1.2 & 0.0 & $3.1 \mathrm{a}$ \\
\hline Castor beans with Eucalyptus $10 \mathrm{~m} \times 4 \mathrm{~m}$ & 1.1 & 0.0 & 0.0 & 0.0 & 0.9 & $2.0 \mathrm{c}$ \\
\hline Cassava with Eucalyptus 10m x 2m & 0.0 & 0.7 & 0.9 & 0.0 & 0.0 & $1.5 \mathrm{~d}$ \\
\hline Cassava with Eucalyptus $10 \mathrm{~m} \times 3 \mathrm{~m}$ & 0.0 & 0.8 & 0.0 & 0.9 & 0.0 & $1.7 \mathrm{~d}$ \\
\hline Cassava with Eucalyptus $10 \mathrm{~m} \times 4 \mathrm{~m}$ & 0.0 & 0.8 & 0.0 & 0.0 & 0.7 & $1.5 \mathrm{~d}$ \\
\hline Coefficient of variation $(\%)$ & & & 10.84 & & & \\
\hline Average & & & 1.59 & & & \\
\hline
\end{tabular}

Values followed by the same letter in the column do not differ significantly according to the Scott-Knott test at the 5\% error probability level. Os valores seguidos pela mesma letra na coluna não diferem significativamente de acordo com o teste de Scott-Knott no nível de probabilidade de erro de $5 \%$.

FLORESTA, Curitiba, PR, v. 51, n. 2, p. 363-370, abril/jun 2021. 


\section{DISCUSSION}

\section{Eucalyptus production}

The higher planting densities resulted in increased volume per hectare, as found by Moulin et al. (2017), who verified the highest production in the area with the closer tree spacing. Ribeiro et al. (2017) reported that in smaller tree spacings, it is common to have a higher number of individuals per area, trees with smaller individual volumes, and higher volume per area. This explains why the $10 \mathrm{~m} \times 2 \mathrm{~m}$ regions had the highest volume per hectare in all systems and ages. If the objective is to produce lumber or wood with larger dimensions, Oliveira et al. (2009) recommended the use of $10 \mathrm{~m} \times 3 \mathrm{~m}$ and $10 \mathrm{~m} \times 4 \mathrm{~m}$ tree spacing.

The planting density, mainly in an agroforestry system, depends on a balance between a large total volume per hectare and a large individual volume per tree. A high planting density provides the selection of the best specimens for logging, while the smaller trees are more suitable for firewood or charcoal. With a low planting density, growth stagnation is delayed, resulting in more numerous trees with greater individual volumes. However, the selection aspect is compromised by the smaller number of trees available.

Thinning can be used to solve the impasse between planting density and individual tree volume. This technique is used to manage the competition between trees and to increase usable timber production during forest stand rotation (ASHTON and KELTY, 2018). Furthermore, the use of this procedure in an agroforestry system helps to control competition between trees and crops. Therefore, in an agroforestry system, it may be possible to have higher initial densities and use thinning to manage competition among trees and between trees and crops. For example, a system starting with $10 \mathrm{~m} \times 2 \mathrm{~m}$ tree spacing could be thinned to $10 \mathrm{~m} \times 4 \mathrm{~m}$ at 21 months, and generate revenue from the wood.

The Eucalyptus intercropped with castor bean in $10 \mathrm{~m} \times 3 \mathrm{~m}$ spacing showed higher volume production than the other systems at both ages. These results appeared to be related to the positive effects of the intercropped species. In this context, it was noted that the interaction of trees and crops might result in a more efficient use of water, nutrients, and solar radiation than the forest or agricultural monoculture (MACEDO et al., 2018).

In addition to the interaction between components, it is essential to understand the purpose of the agricultural component to the producer since, depending on the spacing of the trees, there will be more or less area available for agricultural production. This assumption influences the area and radiation accessible to the crop.

Some examples of crops that favor the growth and volumetric production of Eucalyptus are, most notably, beans (Phaseolus vulgaris), maize (Zea mays), rice (Oryza sativa), and soybean (Glycine max) (SCHREINER and BALLONI, 1986; MACEDO et al., 2018). However, the proposed system is considered a pioneer, and this positive relationship requires further studies to better understand the factors involved.

\section{Production of the agricultural component}

The amount of light available for the growth of annual crops that comprise the understory of an agroforestry system with Eucalyptus can determine the production potential of the system, since solar radiation passing through the canopy is reduced as the density increases. This factor increases the radiation interception by the canopy and reduces the amount and quality of radiation incident on the agricultural components (MACEDO et al., 2018; CARON et al., 2012; PILAU et al., 2015).

The management of radiation in agroforestry systems can be accomplished by selecting species with low dense crowns and shade tolerance, and altering management operations, such as invoking thinning and choosing the most appropriate spacing distance (MACEDO et al., 2018). The $10 \mathrm{~m} \times 3 \mathrm{~m}$ spacing of the Eucalyptus showed higher castor bean production in the intermediate density of tree lines, where there could be beneficial shading for the crop, which is consistent with the results obtained by Carvalho et al. (2010).

Shading in semiarid regions is essential, since temperatures above $40{ }^{\circ} \mathrm{C}$ cause abortion of flowers, sexual reversion of female flowers to males, and reduction of essential oil content in seeds, thereby impeding the production of castor oil (SILVA et al., 2007). The presence of trees in the production system improves the microclimate and reduces air temperature and evapotranspiration, thus increasing relative air and soil moisture (PILAU et al., 2015).

The cassava and Eucalyptus consortium showed a reduction of $23 \%$ of the average production compared to conventional cultivation (monoculture), likely because of the higher requirement for photosynthetically active radiation (GABRIEL et al., 2014). Light restriction causes physiological responses that stimulate the expansion of the leaf limb and elongation of the stalks and petioles, which reduces the development of the root system (GONDIM et al., 2008). This behavior could promote differential partitioning of biomass, since under heavy shading, cassava plants use a greater amount of photoassimilates for leaf maintenance at the end of the cycle, delaying leaf senescence and translocation of assimilates to the reserve organs, reducing final production (OLIVEIRA et al., 2011).

The cassava monoculture was $9 \%$ more productive than the average in the northern region of the state of Minas Gerais $\left(11,342 \mathrm{~kg} \mathrm{ha}^{-1}\right)$, which highlights the potential for the crop in semiarid regions (IBGE, 2016).

FLORESTA, Curitiba, PR, v. 51, n. 2, p. 363-370, abril/jun 2021.

Nieri, E. M. et.al.

ISSN eletrônico 1982-4688

DOI: $10.5380 /$ rf.v51 i2. 68962 
Despite the lower value of cassava production in the agroforestry systems $10 \mathrm{~m} \times 3 \mathrm{~m}\left(10,338.82 \mathrm{~kg} \mathrm{ha}^{-1}\right)$ and 10 $\mathrm{m} \times 4 \mathrm{~m}\left(10,250.14 \mathrm{~kg} \mathrm{ha}^{-1}\right)$, there was no statistical difference between the monoculture and the agroforestry system production. However, the production of cassava with agroforestry systems was less than expected; they were close to the regional average production of cassava, which emphasizes the potential use of the system, especially with wide tree row spacing when associating this crop with tree species.

\section{Area equivalence index (AEI)}

The comparison between systems focuses mainly on their efficiency compared to monocultures (ALBUQUERQUE et al., 2012). The area equivalence index (AEI) indicates the sum of the areas required to be cultivated in monoculture with both crops in order to achieve a yield of 1.0 ha of the intercropping system; the higher the index, the more advantageous the system (SANTOS et al., 2016; ARENAS-CORRALIZA et al., 2018).

All systems presented an AEI above 1, which indicates that they were more productive than the respective monocultures. The association between the different components of the agroforestry system has shown to provide a more efficient use of the soil.

The high AEI values found in the Eucalyptus and castor bean consortia are indicators of the high productive potential of this system. In the intercropping system between Eucalyptus and cassava, the AEI values were similar, but varied with increased spacing. This indicates better productive performance with greater tree spacing.

In practice, agroforestry systems should be arranged according to the objectives of the land manager. The results presented can be approached with an agricultural focus, where the space between tree lines should be greater for increased crop area, or they can be interpreted from a forestry perspective, where the tree lines should be closer together to favor wood production.

For example, the productivity of cassava was the same in monoculture and in the system with Eucalyptus $(10 \mathrm{~m} \times 4 \mathrm{~m}$ and $10 \mathrm{~m} \times 3 \mathrm{~m})$. The land manager could focus on agricultural production using the monoculture model, or the system with cassava and Eucalyptus, diversifying production. Using a tree spacing of $10 \mathrm{~m} \times 4 \mathrm{~m}$ would increase the area devoted to cassava production, or taking a forestry approach, using a tree spacing of $10 \mathrm{~m}$ $\times 3 \mathrm{~m}$ would increase timber production in the same area.

\section{CONCLUSION}

- Agroforestry systems of Eucalyptus intercropped with castor bean and cassava are suitable for the semiarid region.

- A higher wood volume productivity $\left(\mathrm{m}^{3} \mathrm{ha}^{-1}\right)$ was obtained at a tree spacing of $10 \mathrm{~m} \times 2 \mathrm{~m}$.

- A higher crop yield was obtained at $10 \mathrm{~m} \times 3 \mathrm{~m}$ for castor bean; for cassava, the highest crop yield was obtained with a monoculture and in the system at $10 \mathrm{~m} \times 3 \mathrm{~m}$ or $10 \mathrm{~m} \times 4 \mathrm{~m}$ tree spacing.

\section{REFERENCES}

ALVARES, C. A.; STAPE, J. L.; SENTELHAS, P. C.; GONÇALVES, J. L. M.; SPAROVEK, G. Köppen's climate classification map for Brazil. Meteorologische Zeitschrift, Stuttgart, v. 22, n. 6, p. 711 - $728,2013$.

Albuquerque, J. A. A.; SediyamA, T.; Alves, J. M. A.; SilvA, A. A.; UCHÔA, S. C. P. Cultivo de mandioca e feijão em sistema consorciados realizados em Coimbra, Minas Gerais, Brasil. Revista Ciência Agronômica, Fortaleza, v. 43, n. 3, p. 532-538, 2012.

ARENAS-CORRALIZA, M. G.; LÓPEZ-DÍAS, M. L.; MORENO, G. Winter cereal production in a Mediterranean silvoarrable walnut system in the face of climate change. Agriculture, Ecosystem \& Environment, Amsterdam, v. 264, n. 1, p. 118-111, 2018.

ASHTON, M. S.; KELTY, M. J. The practice of silviculture: applied forest ecology. 10th ed. New York: John Wiley \& Sons, 2018. 731p.

CARON, B. O.; SOUZA, V. Q.; COSTA, E. C.; ELOY, E.; BEHLING, A.; TREVISAN, R. Interceptação da radiação luminosa pelo dossel de espécies florestais e sua relação com o manejo das plantas daninhas. Ciência Rural, Santa Maria - RS, v. 42, n. 1, p.75-82, 2012.

CARVAlho, E. V.; SÁ, C. H. A. C.; COSTA, J. L.; AFFÉRRI, F. S.; SEIBENEICHLER, S. C. Densidade de plantio em duas cultivares de mamona no Sul do Tocantins. Revista Ciência Agronômica, Fortaleza, v. 41, n. 3, p. 387-392, 2010. 
DUARTE, E. A. A.; MELO FILHO, P. A.; SANTOS, R. C. Características agronômicas e índice de colheita de diferentes genótipos de amendoim submetidos a estresse hídrico. Revista Brasileira de Engenharia Agrícola e Ambiental, Campina Grande - PB, v. 17, n. 8, p. 843-847, 2013.

GABRIEL, L. F.; STRECK, N. A.; UHLMANN, L. O.; SILVA, M. R.; SILVA, S. D. Mudança climática e seus efeitos na cultura da mandioca. Revista Brasileira de Engenharia Agrícola e Ambiental, Campina Grande PB, v. 18, n. 1, p. 90-98, 2014.

GONDIM, A. R. O.; PUIATTI, M.; VENTRELLA, M. C.; CECON, P. R. Plasticidade anatômica da folha de taro cultivado sob diferentes condições de sombreamento. Bragantia, Campinas - SP, v. 67, n. 4, p. 1037-1045, 2008. Instituto Brasileiro de Geografia e Estatística - IBGE 2016. Pesquisa agropecuária municipal: Área plantada ou destinada à colheita, área colhida, quantidade produzida, rendimento médio e valor da produção dos principais produtos das lavouras temporárias. https://sidra.ibge.gov.br/tabela/1612\#resultado. 15 de ago. de 2019.

MACEDO, R. L. G., VALE, A. B., CARVALHO, F., VENTURIN, N. NIERI, E. M. Eucalipto em sistemas agroflorestais. 2. ed. Ampliada e revisada. Lavras: Editora UFLA. 2018. 331 p.

MATEUS, G. P., CRUSCIOL, C. A. C., HIRATA, A. C. S., ARAÚJO, H. S. Adubação nitrogenada em cultivares de mamona no sistema de semeadura direta consolidada. Magistra, Cruz das Almas - BA, v. 27, n. 4, p. 460-467, 2015.

MEAD, R.; WILLEY, R.W. The concept of a "Land Equivalent Ratio" and advantages in yields from intercropping. Experimental Agriculture, Cambridge, v. 16, n. 3 p. 217-228, 1980.

MOULIN, J. C.; ARANTES, M. D. C.; OLIVEIRA, J. G. L.; CAMPINHOS, E.; GOMES, F.; VIDAURRE, G. B. Efeito do espaçamento, idade e irrigação no volume e densidade básica do eucalipto. Floresta e Ambiente, Seropédica-RJ, v. 24, n. p. 1-10, 2017.

NIERI, E.M.; MACEDO, R.L.G.; MARTINS, T.G.V.; MELO, L.A.; VENTURIN, R.P.; VENTURIN, N. Comportamento silvicultural de espécies florestais em arranjo para integração pecuária floresta. Floresta, Curitiba-PR, v. 48, n. 2, p.195-202, 2018.

OLIVEIRA, T. K.; MACEDO, R. L. G.; VENTURIN, N.; HIGASHIKAWA, E. M. Desempenho silvicultural e produtivo de Eucalipto sob diferentes arranjos espaciais em sistemas agrossilvipastoril. Pesquisa Florestal Brasileira, Colombo-PR, n. 60, p.1-9. 2009. Special edition.

OLIVEIRA, F. L.; ARAUJO, A. P.; GUERRA, J. G. M. Crescimento e acumulação de nutrientes em plantas de taro sob níveis de sombreamento artificial. Horticultura Brasileira, Brasília - DF, v. 29, n. 3, p. 291-298, 2011.

PILAU, J.; ELLI, E. F.; NARDINO, M.; KARCELSKI, C.; SCHMIDT, D.; CARON, B. O. Desenvolvimento e qualidade do azevém no sub-bosque de angico-vermelho em sistema silvipastoril. Comunicata Scientiae, Bom Jesus, v. 6, n.4, p. 437-444, 2015.

RIBEIRO, M. D. S. B.; JORGE, L. A. B.; MISCHAN, M. M.; SANTOS, A. L.; BALLARIN, A. W. Avaliação da produção de biomassa do fuste de um clone híbrido de eucalipto sob diferentes espaçamentos. Ciência Florestal, Santa Maria - RS, v. 27, n.1, p. 31-45, 2017.

SANTOS, M. A.; BATISTA, P. S. C.; LOPES, M. F.; SILVA, M. G. M.; BERTO, A. L. F. Desempenho agronômico de milho consorciado com feijão-de-corda em diferentes populações e arranjos de plantas no semiárido mineiro. Revista Agro@mbiente On-line, Boa Vista, v. 10, n.3, p. 201-208, 2016.

SCHREINER, H. G., BALLONI, E. A. Consórcio das culturas de feijão (Phaseoulus vulgaris L.) e Eucalipto (Eucalyptus grandis W. Hill ex Maiden) no Sudeste do Brasil. Boletim de Pesquisa Florestal, Colombo-PR, v.12, p. 83-104, 1986.

SILVA, P. C. G; MOURA, M. S. B; KIILL, L. H. P; BRITO, L. T. L; PEREIRA, L. A.; SÁ, I. B.; CORREIA, R. C.; TEIXEIRA, A. H. C.; CUNHA, T. J. F.; FILHO, C. G. Caracterização do Semiárido brasileiro: fatores naturais e humanos. In: SA, I. B.; SILVA, P. C. G. da. Semiárido brasileiro: pesquisa, desenvolvimento e inovação. Petrolina: (Ed.) Embrapa Semiárido, 2010, cap. 1, p. 18-48.

SILVA, T. R. B.; LEITE, V. E.; SILVA, A. R. B.; VIANA, L. H. Adubação nitrogenada em cobertura na cultura da mamona em plantio direto. Pesquisa Agropecuária Brasileira, Brasília - DF, v. 42, n. 9, p. 1357-1359, 2007.

SOARES, M. R. S.; NASCIMENTO, R. M.; VIANA, A. E. S.; CARDOSO, A. D.; MAGALHÃES, G. C.; FOGAÇA, J. J. L. Componentes agronômicos qualitativos e caracterização morfológica de variedades de

FLORESTA, Curitiba, PR, v. 51, n. 2, p. 363-370, abril/jun 2021.

Nieri, E. M. et.al.

ISSN eletrônico 1982-4688 
mandioca (Manihot esculenta Crantz) em seis épocas de colheita. Scientia Plena, São Cristóvão - SE, v. 13, n. 6 , p. 1-12, 2017.

SOBBULAKSHMI, V.; SRINIVASAN, K.; DIVYA, M. P.; MANI, S. Effect of spacing and intercropping on the growth of Jatropha curcas and availability of light under Agroforestry System in Tamil Nadu, India. International Journal of Current Microbiology and Applied Sciences, v. 8, n. 6, p. 995-1002, 2019.

FLORESTA, Curitiba, PR, v. 51, n. 2, p. 363-370, abril/jun 2021. 